\title{
Fungsi Humas dalam Menjalin Hubungan di Pemerintahan Kota Bukittinggi
}

\author{
Suci Wahyuni Multi ${ }^{1}$, Syamsuar Syam ${ }^{2}$, Usman $^{3}$, Arina Fransiska ${ }^{4}$ \\ Universitas Islam Negeri Imam Bonjol Padang \\ ${ }^{1}$ Email : suciwahyunimulti@gmail.com \\ ${ }^{2}$ Email : syamsuarsyam@uinib.ac.id \\ 32Email : usmanma@uinib.ac.id \\ ${ }^{4}$ Email : arinafransiska@uinib.ac.id
}

\begin{abstract}
The purpose of this study is to know the function of public relations in maintaining, maintaining internal and external relations within the city government Bukittinggi. The research was motivated by negative issues circulating from the public among the Bukittinggi city government. The achievements of the City Government of Bukittinggi in a short time together with the problems that came, such as the fire of the Pasar Atas trade center which is the economic hub of the city of Bukittinggi, the central convection fire market Aur Kuning which is the largest wholesale and retail navel in West Sumatra. This study uses descriptive qualitative research methods. Data collected in the form of words, pictures and script interviews, notes in the field, photos, personal documentation and other official documentation. The results of this study reveal that the Public Relations Section for the Government of the city of Bukittinggi is a very important and very necessary need in the government. Especially related to meeting the community's need for information. The function of public relations is to communicate and inform the public about work plans, performance, and results achieved by the government. And establish a harmonious relationship with various parties. The function of public relations in the Bukittinggi city government is also to absorb aspirations from public reaction.
\end{abstract}

Keywords: Functions of Public Relations; the City Government; Information

\begin{abstract}
ABSTRAK
Tujuan penelitian ini untuk mengetahui fungsi humas dalam menjaga, memelihara hubungan Internal dan Eksternal di lingkup pemerintah kota Bukittinggi. Penelitian dilatarbelakangi oleh isu-isu negative yang beredar dari kalangan publik di tengah-tengah pemerintah kota Bukittinggi. Prestasi yang diraih Pemerintah Kota Bukittinggi dalam waktu singkat bersamaan dengan masalah yang datang, seperti kebakaran pusat perdagangan Pasar Atas yang merupakan lambung perekonomian kota Bukittinggi, kebakaran pusat konveksi pasar Aur Kuning yang merupakan pusar grosir dan eceran terbesar di Sumatra Barat. Penelitian ini menggunakan metode penelitian kualitatif deskriptif. Data yang dikumpulkan berupa kata-kata, gambar dan naskah wawancara, catatan di lapangan, foto, dokumentasi pribadi dan dokumentasi resmi lainnya. Hasil penelitian ini mengungkapkan Bagian Humas bagi Pemerintah kota Bukittinggi menjadi sebuah kebutuhan yang sangat penting dan sangat dibutuhkan dalam pemerintahan. Terutama berkaitan dengan pemenuhan kebutuhan masyarakat akan informasi. Fungsi humas
\end{abstract}


untuk mengkomunikasikan dan menginformasikan kepada publik tentang rencana kerja, kinerja, dan pencapaian hasil yang dilakukan pemerintah. Serta menjalin hubungan yang harmonis dengan berbagai pihak. Fungsi humas pemerintah kota Bukittinggi juga untuk menyerap aspirasi dari reaksi publik.

Kata Kunci : Fungsi Humas; Pemerintah Kota; Informasi

\section{PENDAHULUAN}

Bagian terpenting dari sebuah lembaga atau organisasi adalah bagian hubungan masyarakat (Humas) atau sering disebut Public Relations. Public Relations sering disingkat dengan PR, merupakan suatu kegiatan menanamkan dan memperoleh pengertian, kepercayaan, dari masyarakat umumnya. Dalam Public Relations terdapat usaha untuk mewujudkan hubungan yang harmonis antara suatu badan dengan publiknya. Menurut Onong Uchjana Effendy (1981) humas adalah komunikasi dua arah antara organisasi dengan publik secara timbal balik dalam rangka mendukung fungsi dan tujuan manajemen dengan meningkatkan pembinaan kerja sama dan pemenuhan kepentingan bersama.

Peran humas dalam sebuah organisasi atau instansi sangatlah penting. Dalam kegiatan humas ada dua peran besar yang secara konsisten muncul dalam kegiatan humas yaitu peran sebagai teknisi dan manajemen. Peran sebagai teknisi mewakili seni dari humas seperti menulis, mengedit, membuat rilis berita, mengambil foto, menjalin hubungan dengan pers. Peran sebagai manajemen berfokus pada kegiatan yang membentuk organisasi dalam mengidentifikasi dan memecahkan masalah terkait dengan humas. Peran humas dalam sebuah organisasi atau instansi sangatlah penting. Dalam kegiatan humas ada dua peran besar yang secara konsisten muncul dalam kegiatan humas yaitu peran sebagai teknisi dan manajemen. Peran sebagai teknisi mewakili seni dari humas seperti menulis, mengedit, membuat rilis berita, mengambil foto, menjalin hubungan dengan pers. Peran sebagai manajemen berfokus pada kegiatan yang membentuk organisasi dalam mengidentifikasi dan memecahkan masalah terkait dengan humas.

Kota Bukittinggi saat ini menjadi salah satu sorotan publik baik lokal maupun nasional. Dalam lingkup Sekretariat Daerah Kota Bukittinggi yang mana pada saat ini begitu banyak prestasi yang diraih dalam waktu singkat, dan tak lepas juga dari bertubi-tubimasalah yang dating pada pemerintah Kota Bukittinggi seperti kebakaran pusat perdagangan Pasar Atas yang merupakan lambung perekonomian kota Bukittinggi, kebakaran pusat konveksi pasar Aur Kuning yang merupakan pusar grosir dan eceran terbesar di Sumatra Barat. Dengan banyaknya masalah yang datang tersebut begitu pula datangnya isu-isu negative yang beredar dari kalangan publik di tengah-tengah pemerintah kota Bukittinggi. Dalam lingkup pemerintah kota Bukittinggi terutama bagian humas memiliki Sumber Daya Manusia (SDM) yang merupakan salah satu faktor sangat penting bahkan tidak dapat dilepaskan dari sebuah organisasi, baik institusi 
maupun perusahaan. SDM juga merupakan kunci yang menentukan perkembangan perusahaan. Pada hakekatnya, SDM berupa manusia yang bekerja di sebuah organisasi sebagai penggerak, pemikir dan perencana untuk mencapai tujuan organisasi itu. SDM yang ada di humas pemerintah Kota Bukittinggi sangatlah tidak cukup terutama di bagian jurnalistik, merupakan bagian terpenting dari semua bagian yang ada di humas. Sebab bagian inilah yang menjadi penghubung antara masyarakat dengan pemerintah. Setiap kegiatan yang diadakan oleh lingkup pemerintah, humas merupakan media penyebarluasan ke tengah masyarakat terutama bagian jurnalistik.

\section{KAJIAN TEORI}

Hubungan Masyarakat yang disingkat dengan Humas sebagai terjemahan dari istilah Public Relation, atau disingkat dengan PR. Humas menurut definisi Frank Jefkins yang diterjemahkan oleh Daniel Yadin dalam buku yang berjudul public relation adalah suatu bentuk komunikasi yang terencana baik itu dalam maupun luar, antara suatu organisasi dengan semua khalayak dalam rangka mencapai tujuan spesifik yang berlandaskan pada saling pengertian. Menurut Edward L. Bernays (publik relation university of Oklohama Press) humas mempunyai 3 pengertian : Memberi penerangan kepada masyarakat, membujuk langsung terhadap masyarakat guna mengubah sikap dan tindakan, usaha-usaha mengintegrasikan sikap dan tindakan dari permasalahan dengan masyarakat dan dari masyarakat terhadap permasalahannya.
Para ahli telah membagi humas menjadi dua jenis pengertian yakni:

\section{Humas sebagai Technique of Communication}

Kegiatan hubungan masyarakat pada hakekatnya adalah kegiatan komunikasi. Komunikasi yang dilancarkan oleh humas mempunyai cir-ciri tertentu yang disebabkan oleh fungsi hubungan masyarakat, sifat organisasi di mana humas itu dilakukan, sifat manusia yang terlibat, dan faktor-faktor eksternal yang mempengaruhi. Ciri hakiki yang komunikasi dalam humas yaitu adanya komunikasi dua arah atau timbal balik, ini mutlak harus berlangsung. Hubungan masyarakat dalam Technique of Communication mengandung arti bahwa kegiatan hubungan masyarakat dilakukan sendiri oleh seorang pemimpin, apakah ia pemimpin jawatan, perusahaan, instansi dan organisasi.

\section{Hubungan masyarakat sebagai State of Being}

State of Being di sini adalah keadaan wujud yang merupakan wahana kegiatan humas dalam bentuk biro, bagian, seksi, urusan dan lainnya. Penggunaan istilah tersebut bergantung pada struktur organisasi di mana humas itu dilakukan. Bagian, seksi, urusan hubungan masyarakat sebagai sarana ke bagian hubungan masyarakat jelas dapat dilihat wujudnya. Yakni ruang kantor yang lengkap dengan peralatan dan seluruh pegawainya.

Peranan humas dalam suatu organisasi ada empat kategori menurut Dozier \& Broom yaitu :

Penasehat Ahli di mana humas dianggap sebagai orang yang ahli, 
tugasnya menasehati pimpinan perusahaan atau organisasi

Fasilitator komunikasi di mana peran humas sebagai fasilitator komunikasi antara perusahaan atau organisasi dengan publik. Baik publik eksternal dan internal

Fasilitator proses pemecahan masalah di mana peran petugas humas sebagai fasilitator dalam pemecahan masalah. Pada peran ini petugas humas melibatkan diri atau dilibatkan dalam setiap manajemen

Teknisi komunikasi di mana petugas humas dianggap sebagai pelaksana teknis komunikasi dan tugasnya menyediakan layanan di bidang teknis, sementara kebijakan dan keputusan teknik komunikasi mana yang akan digunakan bukan merupakan keputusan petugas humas.

Tujuan utama humas yaitu penyelenggara komunikasi timbal balik antara suatu organisasi dan publik yang berpengaruh atas tujuan organisasi. Tujuan untuk menciptakan saling pengertian dan dukungan bagi tercapainya tujuan kebijakan dan tindakan organisasi. Mengenai humas pemerintah dapat dijelaskan bahwa humas pada lembaga atau instansi mempunyai dua tugas yaitu :Pertama menyebarkan informasi secara teratur mengenai kebijaksanaan, perencanaan, dan hasil yang telah dicapai, Kedua menerangkan dan mendidik publik mengenai perundangundangan, peraturan dan hal yang bersangkutan dengan kehidupan rakyat sehari-hari.

Dalam buku Efektifitas Publik Relations edisi kesembilan karangan Scott M. Cutlip, Allen H. CenterdanGlent M.
Broom menjelaskan beberapa fungsi Publik Relations yaitu :

1. Hubungan Publik Internal

Hubungan internal merupakan bagian khusus dari PR yang membangun dan mempertahankan hubungan baik dan saling bermanfaat antara manajer dan karyawan tempat organisasi menguntungkan kesuksesannya. Aspek yang amat penting bagi organisasi adalah karyawan.

\section{Hubungan Publik Eksternal}

Salah satu tujuan eksternal publik relations adalah untuk mengeratkan hubungan dengan orang-orang di luar badan/ instansi hingga terbentuk opini publik yang favourable terhadap badan itu. Bagi suatu perusahaan/ instansi hubungan dengan publik di luar merupakan suatu keharusan di dalam usaha.

\section{Hubungan dengan Pemerintah}

Dalam suatu organisasi / pemerintahan pada bagian humas perlu ditetapkan seorang petugas khusus yang menangani peraturan pemerintah, yang terutama berkaitan dengan organisasi humas tersebut.

\section{METODE PENELITIAN}

Penulis menggunakan metode kualitatif yang bersifat deskriptif. Tempat penelitian dilakukan di lembaga pemerintah kota Bukittinggi bagian humas Setdako Bukittinggi Jln. Kusuma Bakti Bukit Gulai Bancah Kota Bukittinggi. Untuk mendapatkan data yang dibutuhkan tentang permasalahan yang penulis bahas maka yang menjadi informan dalam penelitian ini adalah Kabag serta Kasubag humas pemerintah 
kota Bukittinggi dan Staff Humas. Penulis menggunakan teknik pengambilan sampel yang diambil dengan cara atau berdasarkan siapa yang di temukan di lokasi penelitian.

Teknik pengumpulan data yang digunakan adalah observasi. Penulis telah melakukan observasi awal dari tanggal 13 September- 29 Desember 2017 di humas pemerintah kota Bukittinggi. Penulis melakukan pengamatan secara langsung di bagian humas pemerintah kota Bukittinggi terkait masalah yang penulis angkat. Selanjutnya penulis melakukan observasi lanjutan di lembaga humas pemerintah kota Bukittinggi terkait permasalahan yang penulis angkat. Teknik selanjutnya adalah wawancara. Wawancara yang penulis lakukan dalam penelitian ini adalah wawancara mendalam yang secara umum merupakan proses memperoleh keterangan untuk tujuan penelitian dengan cara tanya jawab sambil bertatap muka antara pewawancara dan informasi atau orang yang di wawancarai, dengan atau tanpa menggunakan pedoman (guide) wawancara, di mana pewawancara dengan informan terlibat dalam kehidupan sosial yang relatif lama. Adapun wawancara yang penulis lakukan adalah kepada Kabag humas serta staff humas yang terlibat dalam penelitian. Teknik pengumpulan data yang terakhir adalah study dokumentasi. Cara pengumpulan data melalui penilaian serta arsip dan termasuk juga buku tentang pendapat, teori, dalil atau hukum dan lainnya yang berhubungan dengan masalah penelitian.

Teknik pengolahan data yang penulis gunakan adalah pencatatan data, klasifikasi dan analisis data, dan penarikan kesimpulan. Penulis melakukan pencatatan data setelah melakukan observasi dan wawancara dari sumber data yang di perlukan. Selanjutnya adalah adalah klasifikasi dan analisis data. Setelah melakukan analisis data, langkah selanjutnya penulis melakukan penarikan kesimpulan dengan menggunakan alur berfikir deduktif, yaitu cara berfikir yang bertolak dari pernyataan yang bersifat umum dan menarik kesimpulan yang bersifat khusus dan spesifik.

\section{HASIL DAN PEMBAHASAN}

Fungsi humas dalam memelihara hubungan internal Public Relation dapat dilihat senagai berikut :

\section{Fungsi humas dalam menjalin komunikasi}

Fungsi humas dalam memelihara hubungan Internal Public Relations di Pemerintah Kota Bukittinggi dengan menjalin komunikasi yang baik antara atasan dan bawahan serta sesama karyawan. Selain itu, humas juga menjadi komunikator atau juru bicara dalam menyampaikan informasi mengenai Pemerintah Kota Bukittinggi sesuai dengan fungsi humas yaitu memelihara komunikasi yang harmonis antara organisasi dengan publik baik Internal atau Eksternal, menciptakan komunikasi dua arah secara timbal balik dengan menyebarkan informasi dari organisasi ke publik dan menyalurkan opini publik, dan melayani publik serta memberikan nasehat kepada pimpinan organisasi untuk kepentingan umum. Sesuai hasil wawancara yang dilakukan dengan Kepala Bagian (Kabag) Humas Yulman SIP.M.M, menyatakan bahwa: 
Dalam humas menjaga hubungan internal dapat dilakukan dengan cara menjalin komunikasi yang baik antara atasan dengan bawahan atau sesama karyawan. Selain itu humas juga menjalin komunikasi yang baik dengan cara menciptakan komunikasi yang harmonis antara organisasi dengan public, menciptakan komunikasi dua arah dalam menyebarkan informasi. Humas menjadikan karyawan sebagai teman sendiri serta rekan sejawat dalam bekerja, walaupun di dalamnya terdapat perbedaan jabatan antara atasan dan bawahan, namun itu tidak menjadi perbedaan mencolok dalam menjaga hubungan di dalamnya.Dengan menjaga hubungan tersebut timbullah kerja sama dan saling menghargai serta mempercayai di dalamnya antara atasan dan bawahan serta sesama bawahan.

Sesuai dengan pernyataan dari Rafika Rusydi SH sebagai PLH. Kasubag pemberitaan dan penyajian data bahwa:

Hubungan atasan dengan bawahan sangat baik, atasan berfungsi sebagai pimpinan dan pendidik bagi karyawan, yang mendelegasikan tugas sekaligus membimbing bawahan atau karyawan. Keterbukaan antara atasan dan bawahan tentu ada dilihat dari pendelegasian tugas yang cukup jelas, tegas dan tepat, bawahan pun punya aksi informasi jika belum mengerti kepada pemimpin.

Dalam humas ada komunikasi vertikal (atas bawah) dan juga komunikasi Horizontal. Humas pada dasarnya berfungsi untuk menghubungkan publik atau pihak yang berkepentingan di dalam suatu instansi atau lembaga. Hubungan kerja sehari-hari melibatkan banyak kontak, tetapi komunikasi karyawan yang efektif akan berkembang dalam iklim yang jujur dan dapat dipercaya. Komunikasi yang di lakukan atasan ke bawahan tidak akan mengalami kesulitan, ini disebabkan karena faktor Psikologis, sosiologi dan pendidikan. Sebagaimana pernyataan Kabag Humas Yulman SIP MM menyebutkan bahwa:

Hubungan antara atasan dan bawahan berjalan dengan baik antara Kabag dengan Kasubag maupun Kasubag dengan staff. Tapi ada sedikit kendala antara Kasubag dengan staff, itu pun hanya sebagian disebabkan staff ada yang merasa kurang nyaman, ketidaktahuan, dan ketidak keterbukaan, sehingga timbullah hubungan tidak harmonis. Itu merupakan sifat manusiawi karena kantor di latar belakangi berbagai status sosial.

Salah satu cara untuk mengatasi kesulitan hubungan antara bawahan dan atasan yang tidak harmonis yaitu dengan cara memberikan kesempatan kepada karyawan untuk menyatakan pendapat dengan bebas. Serta memberikan peluang bagi karyawan untuk mengembangkan karirnya. Publik relation bukan hanya duduk di kantor melainkan harus berkomunikasi langsung dengan karyawan.

Mencapai karyawan yang mempunyai kegairahan kerja adalah tujuan internal publik relations. Semua itu dapat diciptakan apabila pimpinan memperhatikan kepentingan para pegawai baik ditinjau dari segi ekonomi, sosial maupun psikologi. Kesejahteraan seperti kesehatan dan tempat bekerja para karyawan dapat mempengaruhi kelancaran aktivitas dalam badan itu. Antara pimpinan dan yang di pimpin termasuk keluarga kedua belah pihak dan 
antara teman sejawat harus ada hubungan yang konstan dan baik, sehingga mereka dapat merupakan suatu keluarga yang saling mengerti, menghargai. dan mempercayai.

Dari hasil penelitian yang sudah dijabarkan sebelumnya, maka dapat diketahui bahwa fungsi Humas dalam memelihara hubungan Internal Publik Relations adalah menjaga hubungan yang harmonis antara atasan dan bawahan atau sesama bawahan dalam melaksanakan kerja di Pemerintahan Kota Bukittinggi. Selalu ada keterbukaan di antara staf maupun atasan, sehingga dengan adanya keterbukaan dan hubungan yang harmonis akan terjalin kerja sama dan saling percaya serta saling menghargai dan menghormati.

\section{Fungsi humas dalam menjalin kerja sama dengan media dan wartawan}

Bagian Humas Pemerintahan Kota Bukittinggi khusus pada Kasubag Bagian Kemitraan Pers dan Media mempunyai pertimbangan dalam memilih media yang akan di gunakan oleh humas dalam menyebarkan informasi mengenai kegiatan Pemerintahan Kota Bukittinggi. Humas juga mengadakan kerja sama dengan media yang menjadi langganan dalam menyampaikan informasi. Selain kerja sama humas juga melakukan tindakan terhadap media yang tidak berperan aktif di saat menyebarkan informasi. Sebagaimana pernyataan yang di sampaikan oleh Kasubag Bagian Kemitraan Pers dan Media Ermon HB sebagai berikut:

Humas memiliki pertimbangan dalam memilih media yang akan digunakan dalam menyebarkan informasi, pertimbangan tersebut diantaranya, media yang memiliki tingkat kontribusi pemberitaan yang dapat dipublisitaskan melalui media. Selain itu kami juga melakukan kerja sama dengan media dalam bentuk humas menyediakan rilis berita yang disajikan melalui website Pemko. Bagi media yang cukup aktif mempublikasikan berita Pemko akan diberikan Rewoard dalam bentuk lipsus alias liputan khusus. Apabila media yang telah di pilih dan menjadi langganan membuat kesalahan atau tindakan dalam menyebarkan informasi, humas mempunyai tindakan dengan cara melakukan klarifikasi dengan pihak media terkait sumber informasi yang diperoleh atas pemberitaan yang di sampaikan. Selain itu jika masih membuat kesalahan setelah keluar SP alias surat peringatan maka humas mengambil tindakan memutuskan kerja sama dengan pihak terkait11

Bagian Humas melakukan kerja sama dalam menyebarkan informasi dengan beberapa media massa diantaranya :

\section{a. Media cetak}

Media cetak baik harian maupun mingguan yang bekerja sama dengan Bagian Humas Pemerintahan Kota Bukittinggi diantaranya : Koran Harian Padang Ekspres, Singgalang, Post Metro, Koran Padang, Haluan, Metro Andalas, Rakyat Sumbar. Media Cetak Mingguan : Zaman, Bidikkasus, Rakyat Sumbar Mingguan, Indonesia Raya, Sumbar Creative, Lintas Media

\section{b. Media online}

Selain kerjasama dengan media cetak, Bagian Humas Pemerintahan Kota Bukittinggi memerlukan kerjasama dengan media online yaitu Kaba12.com dan Klikpositif. Dalam hubungan kerjasama dengan media online mereka 
mengadakan kontrak di mana media online mengikuti segala aturan yang berlaku di humas tersebut. Setiap berita yang berkaitan dengan pemerintah kota Bukittinggi media online harus menerbitkan, agar setiap masyarakat yang menggunakan media online bisa mengetahui informasi terbaru.

\section{c. Media Elektronik}

Bagian Humas bekerjasama dengan radio yang ada di Kota Bukittinggi diantaranya Radio Rakyat Indonesia (RRI) dan Elsi FM untuk mengisi acara dan program radio tersebut. Humas mengadakan kerjasama dengan radio berupa siaran langsung yang berkaitan dengan pemerintah kota Bukittinggi, rekaman pidato kepala daerah, dialog interaktif.

\section{Fungsi humas dalam melakukan Publisitas}

Informasi yang disebarkan kepada masyarakat melalui publisitas mempunyai kriteria dan bukan sembarang informasi. Dalam penyampaian informasi tersebut humas mencari sasaran atau target yang dituju sebab mempunyai alasan kenapa humas memilih pihak atau sasaran tersebut. Dalam penyampaian informasi tersebut masyarakat ada yang menerima dan ada pula yang menolak. Tidak semua berita atau informasi diterima begitu saja oleh masyarakat. Sebagaimana yang dinyatakan oleh PLH Kasubag pemberitaan dan Penyajian Data Rafika Rusydi menyebutkan bahwa:

Humas mempunyai berita atau informasi kepada masyarakat melalui publisitas. Seperti lewat berita kegiatan Pemerintah Kota Bukittinggi yang diliputi oleh wartawan atau media dan lewat lipsus atau liputan khusus di media. Selain itu berita pemerintah kota ada juga berita kegiatan kepala daerah, kebijakan pemerintah kota, kinerja atau prestasi yang telah diraih pemerintah kota. Jawaban atas berita negatif yang di tayangkan pemerintah daerah. Informasi atau berita tersebut, sasarannya atau ditujukan kepada masyarakat kota Bukittinggi, wartawan media dan ASN pemerintah kota Bukittinggi, alasan humas memilih sasaran tersebut karena pihak itulah yang mengakses dan membaca media setiap hai sesuai kebutuhan masing-masing, tentu semua yang di sampaikan kepada masyarakat tidak lepas dari pro-kontra masyarakat terhadap informasi tersebut. Ada yang memberikan respon negatif dan ada yang respon positif, itu sudah masuk wajar karena sifat manusiawi masyarakat.

Dari pernyataan di atas dapat cermati bahwa tidak semua berita yang humas sampaikan melalui media dengan cara publisitas diterima di tengah-tengah masyarakat. Karena faktor sifat manusiawi masyarakat yang mempunyai pemikiran berbeda-beda dan tidak selalu sama. Ada yang pro dan kontra. Perbedaan pemikiran itulah bagian humas pemerintah kota Bukittinggi harus bisa memberi masukan dan penjelasan kepada masyarakat. Sehingga masyarakat yang tidak faham sebenarnya tentang informasi tersebut bisa mengerti setelah dijelaskan kebenarannya. Itulah fungsi dan tujuan humas di mana bisa menjembatani informasi antara pemerintah dengan masyarakat. 


\section{KESIMPULAN}

Fungsi Bagian Humas membangun hubungan yang positif antara lembaga yang diwakilinya dengan publik internal dan eksternal. Juga berupaya menciptakan saling pengertian, kepercayaan, dukungan, kerjasama dan toleransi antara kedua belah pihak tersebut. Di dalam hubungan Internal harus ada keterbukaan dan saling memahami antara satu dengan yang lain, antara atasan dan bawahan serta antara karyawan, dengan demikian akan terciptanya hubungan yang harmonis dan timbul kerjasama.

Humas merupakan jembatan antara Pemerintah dan masyarakat dalam menyampaikan informasi atau berita dengan kata lain hubungan Eksternal humas harus baik dengan masyarakat sekeliling lembaga, dengan dinas lain dan pemerintahan lainnya. Sehingga akan terciptanya kerjasama dengan pihak terkait.

\section{DAFTAR KEPUSTAKAAN}

Abdurrachman, Oemi, Dasar-dasar Publik Relations, Bandung: Alumni, 1986

Alow, Liliweri. Strategi Komunikasi Masyarakat. Yogyakarta: PT. Printing Cemerlang. 2010

Burhan, Bungin, Analisis Data Penelitian Kualitatif, Jakarta : PT. Raja Grafindo Persada, 2010

Cutlip. M, Scott, Center. H. adlent, Broom.

M. Glen. Efektifitas Publik Relation.

Kencana:

Prenada Media Group. 2006

Effendi, Onong Uchjana, Hubungan Masyarakat, Bandung: PT. Remaja Rosdakarya, 1981
, Human Relations

dan Publik Relations dalam Management, Bandung:

alumni, 1981

Masyarakat $\quad$ Suatu $\begin{array}{r}\text { Hubungan } \\ \text { Studi }\end{array}$

Komunikasi, Bandung: PT. Remaja

Rosdakarya, 2002

Kriyantono, Rachmat, Public Relations

Writing Media Publik Relations Membangun Citra

Korporat, Jakarta: Kencana Prenada Media Group, 2008

Lestari, Wahyuningsih, Tugas dan Fungsi Public Relations dalam Organisasi. Yogyakarta:

prenada media Group, 2013

Nuraki, Aziz, The Secret of Succesfuls Public Relations, Jakarta: Bumi Aksara, 1995

Ruslan, Rosady, Metode Penelitian Public Relations dan Komunikasi, Jakarta: PT. Raja

Grafindo persada, 2003

Suhandang, Kustadi, Public Relations Perusahaan :Kajian Program dan Implementasi,

Bandung: Nuansa yayasan Nusa Cendaka, 2004

Widjaja. Komuniksi, Komunikasi Hubungan Masyarakat. Jakarta: Bumi Aksara. 2010

Wiratha, Metode Penelitian, Yogyakarta: C.V Adi Offset, 2006

Yulman, Kabag Humas Pemerintahan Kota Bukittinggi, wawancara langsung, 17 Oktober 2018

Rafiak Rusydi, PLH. Kasubag Pemberitaan dan Penyajian Data, bagian Humas Pemerintahan

Kota Bukittinggi, wawancara langsung, 02 November 2018. 
Ermon HB, Kasubag Kemitraan Pers dan

Media, bagian Hums Pemerintahan

Kota Bukittinggi,

wawancara langsung, 26 Oktober 2018.

http;//kaba12.com/berita//DPRD-

Bukittinggi-gelar-rapat-terbuka-

dengan-pemerintah-kota-dan

juga-revitalisasi-pedestrian-Jam-Gadang,

08/10/2018, 14.30 wib. 